\title{
An outline of SARS-CoV-2 pathogenesis and the complement cascade of immune system
}

\author{
Padmalochan Hembram*
}

\begin{abstract}
Background: Coronavirus disease 19 is a viral infection caused by a novel coronavirus, SARS-CoV-2. It was first notified in Wuhan, China, is now spread into numerous part of the world. Thus, the world needs urgent support and encouragement to develop a vaccine or antiviral treatments to combat the atrocious outbreak.

Main body of the abstract: The origin of this virus is yet unknown; however, rapid transmission from human-tohuman "Anthroponosis" has widely confirmed. The world is witnessing a continuous hike in SARS-CoV-2 infection. In light of the outbreak of coronavirus disease 19, we have aimed to highlight the basic and vital information about the novel coronavirus. We provide an overview of SARS-CoV-2 transmission, timeline and its pathophysiological properties which would be an aid for the development of therapeutic molecules and antiviral drugs. Immune system plays a crucial role in virus infection in order to control but may have dark side when becomes uncontrollable. The host and SARS-CoV-2 interaction describe how the virus exploits host machinery and how overactive host immune response can cause disease severity also addressed in this review.
\end{abstract}

Short conclusion: Safe and effective vaccines may be the game-changing tools, but in the near future wearing mask, washing hands at regular intervals, avoiding crowed, maintaining physical distancing and hygienic surrounding, must be good practices to reduce and break the transmission chain. Still, research is ongoing not only on how vaccines protect against disease, but also against infection and transmission.

Keywords: COVID-19, SARS-CoV-2, PRR, PAMPs, SARS, Acute respiratory syndrome, Angiotensin-converting enzyme 2

\section{Background}

In late 2019, many unexplained pneumonia cases observed in Wuhan, China, and the outbreak was confirmed to be caused by a coronavirus (Jin et al. 2020a; Wu et al. 2020b; Liu et al. 2020b). Coronaviruses (CoVs) cause multiple respiratory damages and intestinal infections (Channappanavar and Perlman 2017; Song et al. 2019). In severe cases, they can cause life-threatening pneumonia and bronchiolitis. Individuals with the impaired immune system are at high risk to this infection (Zhang and Liu 2020; Yi et al. 2020). It belongs to the same family

*Correspondence: hpadmalochan2020@gmail.com Department of Botany, Berhampur University, Bhanja Bihar, Berhampur 760007, India of viruses responsible for severe acute respiratory syndrome (SARS) and Middle East respiratory syndrome (MERS) because the genetic sequencing sample of this virus shows about $80 \%$ similarity with SARS-CoVs and it shows the same symptoms as SARS and MERS (Ashour et al. 2020).

\section{Main text}

According to the International Committee on Taxonomy of Viruses (ICTV) nomenclature name of new coronavirus $(\mathrm{nCoV})$ fallen as SARS-CoV-2 and the disease as COVID-19 (Jin et al. 2020b; Acter et al. 2020; Nandy 2019; Paudel et al. 2020). Novel coronavirus 2019 is a spherical shaped like other coronaviruses (Wu et al. 2020c; Kim et al. 2020). The virus has a capsid formed by 
$\mathrm{N}$-protein (nucleocapsid protein) where the viral genome packed inside. The capsid is further covered by envelope where various structural proteins are found (Vennema et al. 1996; Shi et al. 2020; Chaudhary et al. 2020). There are three essential structural proteins found on the envelope surface. These are spike proteins $(\mathrm{S})$, membrane protein (M) and envelope protein (E). Among these, $\mathrm{S}$-protein shows protrusion and mediates virus entry into the host cell and gives the crown-like appearance to the virus shown in Fig. 1.

Coronavirus is positive-sense single-stranded RNA genome viruses that found widely in humans and mammals. In pandemic history, coronavirus was first identified in 2002 of SARS CoV, the causative agent for the severe acute respiratory syndrome (Khan et al. 2020; Pillaiyar et al. 2020; Pal et al. 2020). In 2013, MERS-CoV was identified in Middle Eastern countries for its pathogenicity (Khan et al. 2020; Pillaiyar et al. 2020; Pal et al. 2020). Tremendous research has been carried out on human coronavirus pathogenesis for better understanding and may encourage to discover new potential therapeutic drug or antivirals.

Viral particles exert a complex equilibrium in the host cells by which immune system contributes several responses in the clearance of viruses or to neutralize the infection (Misra et al. 2020). Immune system is always not completely prominent in clearing the virus and viruses evolve various strategies to counteract too. Sometimes, immune system pathways act negatively by invading host cells during acting upon viruses, which is called maladjustive immune system (Rogosnitzky et al. 2020). The innate immune system, an antigen independent response, recruits immune cells mainly involves macrophages, NK cells, dendritic cells. These cells further trigger the production of inflammatory factors which eventually activates cytokines and chemokines. The overproduction of these active inflammatory molecules results cytokine storm by not stopping itself, responsible for attacking and damaging healthy tissues (Rogosnitzky et al. 2020).

There is no clinically approved antiviral drug or vaccines to be used against COVID-19 (Shereen et al. 2020). Over the glove are in great hurry to understand COVID19 and to find the best to treat it (Malik et al. 2020). However, many things remain unknown, but one thing is clarified that $\mathrm{nCoV}$ infection is both highly transmissible and deadly pathogenic (Geng et al. 2020).

\section{COVID-19 the pandemic: spreading like wildfire}

COVID-19, coronavirus disease 2019, is an emerging infectious disease caused by a newly identified coronavirus (Gou et al. 2020). Coronavirus is among the large group of viruses, consisting of RNA as genetic material surrounded by an envelope with spikes of glycoprotein on the surface. People infected by this virus show mild to serious symptoms, from just common cold and fever to discomfort in breathing (Zhu et al. 2020). It may cause pneumonia and kidney failure and lead to death. According to WHO, many people infected with the COVID-19 virus recovered without requiring special treatment (Singhal 2020). Aged people and immunocompromised people having medical issues like diabetes, cardiovascular and cancer are more likely to evolve serious illness (Singhal 2020). There are many cases at present. Both SARS and COVID-19 emerged in China (Wilder-Smith et al. 2020; Porcheddu et al. 2020; Lai et al. 2020). Although COVID-19 virus is not lethal as SARS, the number of infection and death caused by COVID-19 surpasses

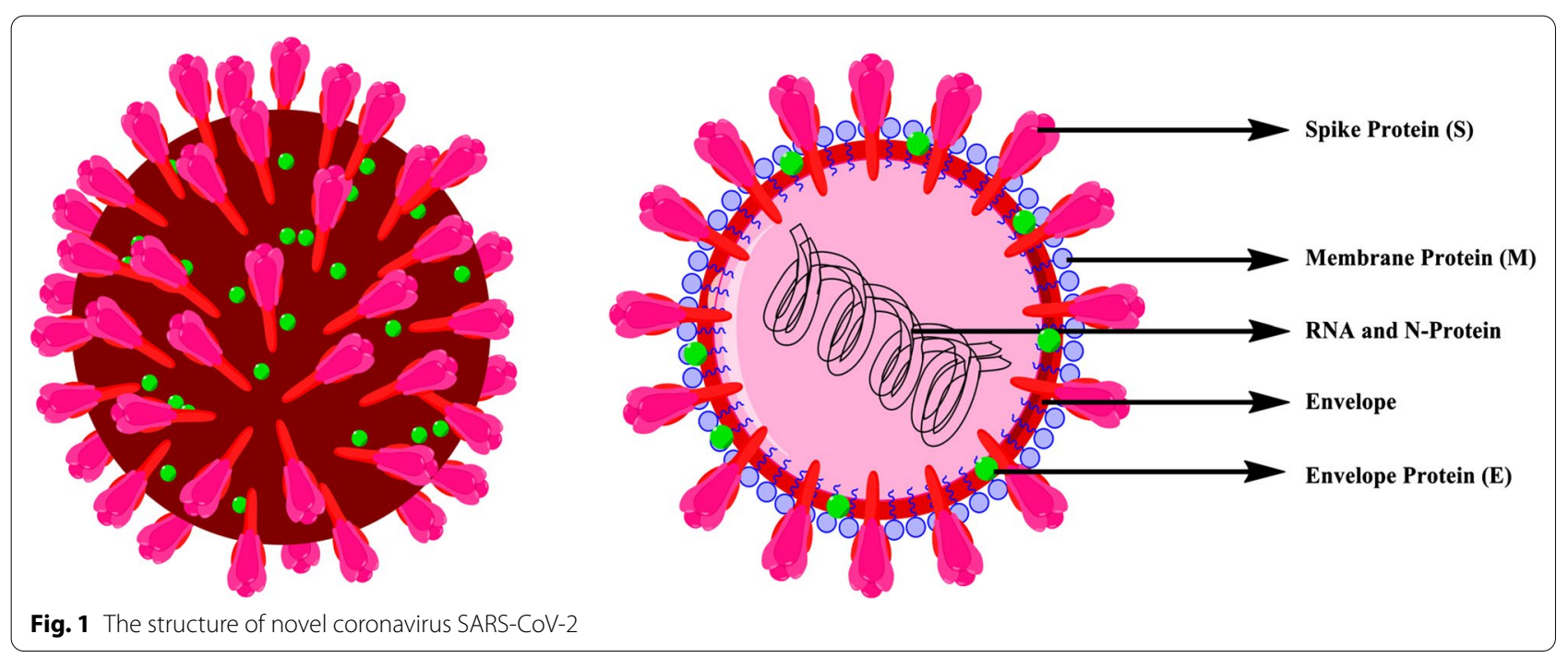


SARS, now declared as a pandemic (Peeri et al. 2020). The outbreak has spread acrimoniously across many countries in a short space of time since coronavirus has posed a global threat to public health (Brown and Wang 2020; Sen et al. 2020).

The international traveling played a critical role in spreading of the coronavirus from Wuhan of China to different nations across the globe (Driggin et al. 2020). Gathering tribes and communities to the metropolis with very poor screening has sparked opportunities for the amplification of infection. However, this epidemic starts in Wuhan, China, but by the middle of January, several countries reported COVID-19 which signified that it was a globalizing disease and no longer China's problem alone (Safdar and Yasmin 2020). Moreover, it had become anthroponosis (person-to-person transmitted disease). The COVID-19 virus transmits primarily through droplets of saliva or mucus-like that discharge when an infected person coughs or sneezes. These respiratory fluids or droplets can infect other people by direct contact or can infect those who pick them up by touching infected surfaces and then their face, nose and eyes (Repici et al. 2020). According to the Centre for Disease Control and Prevention (CDC), US, the COVID-19 causing virus seems to be spreading quickly in the community in the affected geographical areas (Cascella et al. 2020). The outbreak was declared a Public Health Emergency of International Concern and world pandemic announced by the World Health Organization (WHO) (Cascella et al. 2020). Till dated on September 12, 2020, the novel coronavirus has infected more than 28,659,610 individuals globally and has killed more than 919,175 individuals worldwide. The number of infections appearing each day what started in Wuhan, China, has now engulfed over 213 countries.

\section{Coronavirus-host interaction: the basis of disease}

Coronaviruses contain specific genes in ORF1 downstream regions that encode necessary proteins such as structural proteins and which helps in their multiplication (Shafiq et al. 2020; Kumar et al. 2020). The glycoprotein spikes present on the outer-surface of $\mathrm{CoV}$ play the principal role in attachment and entry into host cells (Shereen et al. 2020; Wan et al. 2020). The entry mechanism of coronavirus depends upon cellular proteins such as Human Airway Trypsin-like proteases (HAT), Cathepsins and Transmembrane Protease Serine 2 (TMPRS2), which help in the splitting of spike proteins and lead further penetration. Coronavirus requires AngiotensinConverting Enzyme 2 (ACE2) as a key receptor present in human cells. Binding of spike protein to human ACE2 receptor triggers a conformational change that facilitates membrane fusion through the endosomal pathway which leads in the release of viral genetic material into the host cell cytoplasm. Replication of CoV begins with the translation of ORF1a and 1b into polyproteins pp1a and pplab. These get cleaved proteolytically that give rise to form nonstructural proteins (NSPs) (Shereen et al. 2020; Wan et al. 2020). The NSPs get assembled and form replicase-polymerase that called replication-transcription complex (RTC) (Shereen et al. 2020; Wan et al. 2020). The replicase-polymerase takes part in the replication of viral genomic RNA (gRNA) and transcription of subgenomic RNA. The subgenomic RNA then undergoes translation to produce structural proteins and other accessory proteins (Shereen et al. 2020; Wan et al. 2020). The fast-track assembly of virions happens with the accumulation of gRNA and viral proteins. The process of assembly completes once budding of nucleocapsid has over followed by transport by secretory vesicles and release out of host cell (Shereen et al. 2020; Wan et al. 2020). The route of the assembly to budding takes place in Endoplasmic reticulum to Golgi intermediate complex (ERGIC). Viral entering and replication provide an initial picture of novel coronavirus pathogenesis, elucidated in Fig. 2.

\section{Pathogenesis of SARS-CoV-2}

The pathophysiology of SARS-CoV-2 infection shows a close resemblance to SARS CoV infection with invasive inflammatory reactions highly associated with the consequences of airway damages (Lai et al. 2020; Yang et al. 2020). Respiratory droplets are the primary mode of SARS-CoV-2 transmission, similar to other respiratoryrelated coronaviruses (Prompetchara et al. 2020; Jalava 2020). Individuals infected from novel coronavirus usually exhibit chills, sore throat and dry cough, fever, fatigue and breathing difficulties. Repeated shaking with chills, muscle pain and loss of taste sensation are the new symptoms recently put on by Centre of Disease control, USA, sever covid-19 cases headway with acute respiratory distress syndrome (ARDS), characterized by breathing shortness and low blood oxygen level, which directly lead to respiratory failure (Lai et al. 2020). More than about 65 percent of death cases of COVID-19 fatal cases are associated with ARDS. In a pathological finding in National Health Commission (NHC), China, biopsy specimens from lung, liver and heart tissue of an infected individual, showed alveolar damage, hyaline membrane development, specifying ARDS (Guo et al. 2020). There were few shreds of evidence of interstitial mononuclear inflammatory invades while no utmost injury in heart tissue. And the biopsy samples from liver exhibit modest microvesicular steatosis (Malik et al. 2020). Many patients also show a rise in secondary infections by bacteria and fungi. To cope with viral infection as well as secondary infections, the immune system induces an enormous release 


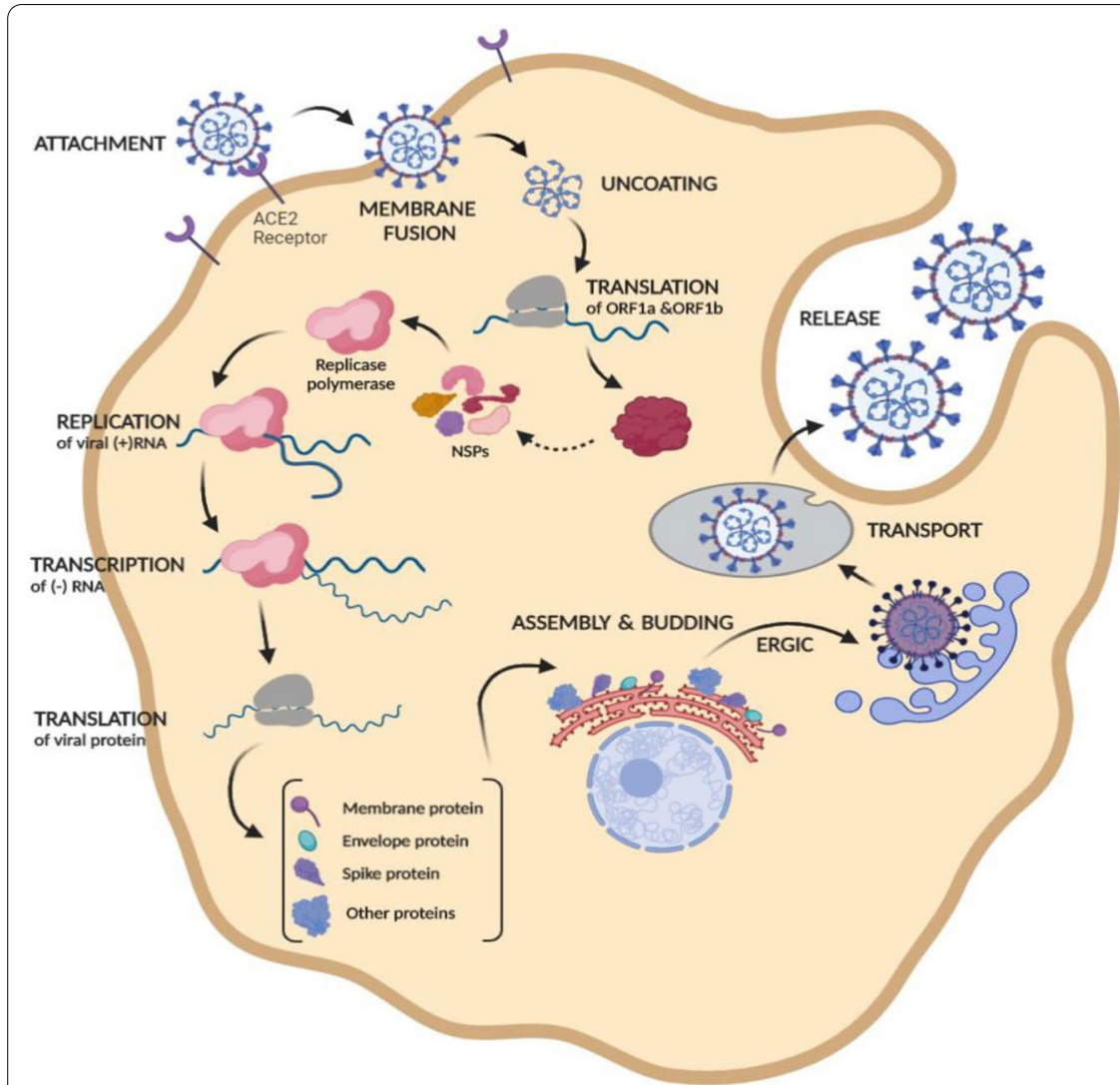

Stages involved in SARS-CoV-2 and host cell interaction

1. Attachment

2. Membrane fusion

3. Uncoating

4. Replication of viral genome

5. Translation of viral protein

6. Assembly and budding

7. Release

Fig. 2 The interaction and lifecycle of coronavirus. Outline of the intracellular obligate parasitic strategy of SARS-CoV-2 to hijack host machinery

of cytokines to result in a cytokine storm, which may lead to sepsis kind of diseases (Kumar et al. 2020; Lai et al. 2020). Cytokines are tiny secreted protein molecules or can be called peptide as well released by immune cells that mediate and regulate immunity and inflammation (Tay et al. 2020). Cytokine storm causes unbalanced inflammation that inflicts multi-organ dysfunction or even leads to organ failure, mainly the cardiac system of heart, the hepatic system of the liver and renal system of kidney gets affected (Russell et al. 2020; Prompetchara et al. 2020; Liu et al. 2020b).

The SARS CoV-2 infects cells by entering into the cell by ACE2 (Zhang et al. 2020a; South et al. 2020; Hoffmann et al. 2020). The replication and release of the virus compel the host cell to face pyroptosis (Moccia et al. 2020). Underlying pyroptosis releases pathogen-associated molecular patterns (PAMPs) and damage-associated molecular patterns (DAMPs), which recognized by surrounding cells that triggers the generation of pro-inflammatory protein molecules. These protein molecules attract immune cells to the site of infection that boost more inflammation. The immune cells may include macrophages, monocytes and T-cells (Tay et al. 2020; Coperchini et al. 2020; Neurath 2020). The cells may damage the air-blood barrier by destroying vascular endothelial cells, and airway epithelial cells result in collateral tissue damage. Airway epithelial cells and endothelial cells show high expression of ACE2 receptor, which is utilized by coronavirus to enter inside the cell. Thus, acute sickness is not only because of viral infection but also overactive immune responses (Zhu et al. 2020).

\section{Immune system response to SARS-CoV-2 attack}

Cascades of viral particles enter into the body, hijack cellular machinery, replicate and multiply and start infecting adjoining cells. Viruses has specific signature pattern on their surface which is called antigens that propel host immune system to produce antibodies. The immune system has two arms, innate and adaptive immunity (Zhang et al. 2020c; Connors and Levy 2020; Felsenstein et al. 2020). The innate immunity response is immediately begun with the recognition of pathogen-associated molecular patterns (PAMPs) through pathogen recognition receptors (PRR). PRR includes several kinds of receptors like Toll-like receptors (TLR), Nod-like receptors (NLR), RIG-I-like receptors (RLR), Lectin-like receptors, etc. TLR recognizes lipids, lipoproteins, nucleic acids, proteins of viruses and other microorganism 
origin. RLR recognizes nucleic acids of RNA viruses, whereas NLR recognizes several components of pathogens and function as inflammasome. Lectin-like receptors is widely expressed in myeloid cells. It takes part in essential signaling pathway that triggers a variety of cellular responses like phagocytosis, chemotaxis of cells and maturation of dendritic cells (Zhang et al. 2020c; Connors and Levy 2020; Felsenstein et al. 2020).

When a virus infect cells, interferon regulatory factors get activated and enhances type-I interferon (IFN) production ( $\mathrm{Li}$ et al. 2020a). The IFNs promote the downstream JAK-STAT signaling cascade, triggers IFNstimulating genes (ISGs) expression. The IFNs has a significant role to reduce virus spread. Interferons are protein molecules only, made by our cells in response to viral infections (Li et al. 2020a; Ghias et al. 2020). Too little interferons at early infection and immoderate production at later could contribute to acute or lethal cases. There are three different groups of interferons found in humans: type I, type II and type III (Rajaei and Dabbagh 2020; Noris et al. 2020). All these categories of interferons are produced by immune cells, but type I is produced by infected cells and type III is produced by epithelial cells. Types I and II produce pro-inflammatory active responses, but type III interferes with viral replication and is less inflammatory. Type III interferons also enhance barrier stability to epithelial cells. But viral particles interact with interferons and other antiviral signaling in host cells to halt their functions (Li et al. 2020a).

Pathogen infection begins with the abrupt activation of complement systems in the host (Zhang et al. 2020c; Connors and Levy 2020; Felsenstein et al. 2020). The complement system is an essential component of innate immunity, plays a critical role in pathogen elimination (Rajaei and Dabbagh 2020; Noris et al. 2020). A persistent encounter of toxins and or pathogens takes place in the airway epithelium from the nasal cavity to alveoli. During this the invaders unclog the mucus and breach the epithelium and when it happens, it must contain complement proteins. For instance, C3 is one of abundant protein found in the bronchial epithelial cells of cystic fibrosis patients. C3a and C5a drive pro-inflammatory mediator upregulation associated with airway epithelial cell injury. So, it suggests that complement proteins are found at alveolar epithelium region to fight against pathogens and pathogen deposits (Magro et al. 2020; Noris et al. 2020). Complement system activation promotes the formation of bioactive molecules like C3 and C5 anaphylatoxins (Smole et al. 2020; Gou et al. 2020). Among complement activation molecules, the $\mathrm{C} 5$ anaphylatoxin is one of the dominant inflammatory peptides (Smole et al. 2020). C5a performs its function when it binds with its receptor $\mathrm{C} 5 \mathrm{aR}$ or $\mathrm{C} 5 \mathrm{aL} 2$. C5aR exhibits higher affinity for C5a expresses on both myeloid cells like neutrophils, basophils, monocytes and non-myeloid cells like bronchiolar and alveolar epithelial and endothelial cells in different organs (like lungs and liver) (Smole et al. 2020; Magro et al. 2020; Gou et al. 2020).

$\mathrm{C} 5 \mathrm{aR}$ is a G-protein coupled receptor which plays a critical role after C5a binding with it (Magro et al. 2020). A high level of C5a has commonly observed in bronchoalveolar lavage fluid (BALF) and serum of individuals infected from respiratory viruses (To et al. 2020; Magro et al. 2020; Guo et al. 2020). C5a is displayed as a potent chemoattractant and recruits inflammatory cells which involves eosinophils, neutrophils, monocytes, macrophages and T-lymphocytes. $\mathrm{C} 5 \mathrm{a}$ also triggers the activation of cytokines and a prolong cytokine release results in "cytokine storm" (Smole et al. 2020; Magro et al. 2020; Gou et al. 2020). Overproduction of C5a is also responsible for the generation of reactive oxygen species (ROS), causes oxidative burst. An experiment carried out in mice infected with influenza virus demonstrates that ROS released from respiratory, immune and inflammatory cells prompts lung damage. C5a modulates innate immunity by inducing immune cells to generate cytokines, including IL-12, tumor necrosis factor- $\alpha$ (TNF) and macrophage inflammatory proteins- $1 \alpha$ (MIP). It also modulates adaptive immune cells to generate IL-1 $\beta$, IL- 6 and IL-8. In an experiment, anaphylatoxin complement system deficient mice infected by SARS-CoV exhibited less respiratory dysfunction and lower the level of cytokines and chemokines in both lung and serum which signifies complement system (C3a, C5a) blockade may alleviate the inflammatory lung complication of COVID-19 (Jiang et al. 2018).

Cytokine storm mediated by $\mathrm{C} 5 \mathrm{a}$ had observed in influenza virus infected individuals ( $\mathrm{Hu}$ et al. 2016). C5a downregulates TLR4 (Toll-Like Receptor) to induce IL-12 family cytokine expression that can play a critical role in amplifying acute lung injury (ALI) and ARDS (Xiang and Fan 2010; Hashimoto et al. 2004; Puneet et al. 2005). Thus, elevated levels of pro-inflammatory cytokines and chemokines produced in response to novel coronavirus might be a reason for causing ALI, ARDS and multi-organ failure, illustrated in Fig. 3. Therefore, inhibiting cytokine and chemokine production can have a protective effect against maladaptive inflammatory response during coronavirus infection.

\section{The antiviral treatment approach for SARS-CoV-2: an urgent need}

Formulating potential vaccine, particularly for the virus, is a time enduring process. Antibodies from recovered patients are already tested and used, which can also act potential treatment for the infection. (Ludwig and 


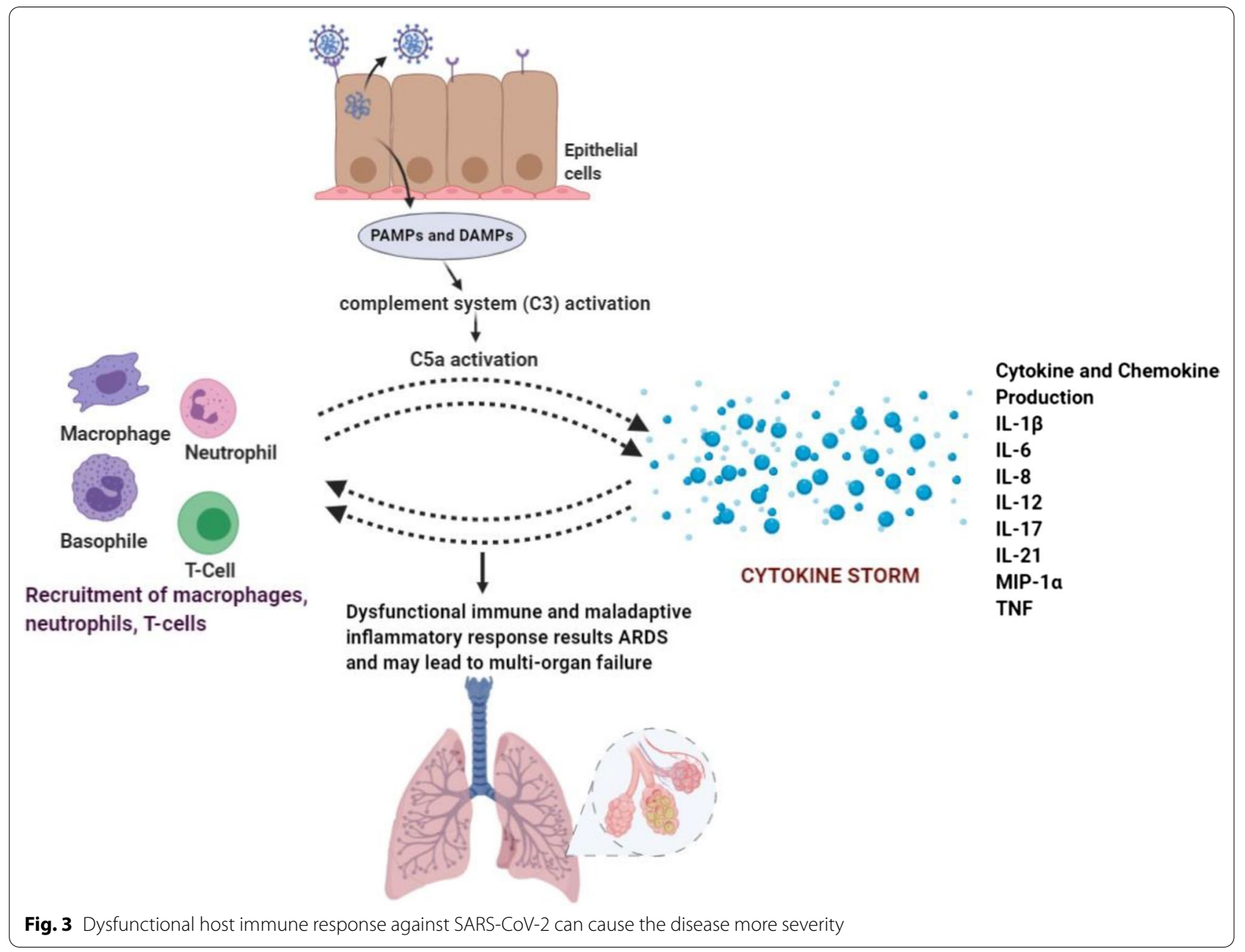

Wagner 2007; Daughton 2020; Lega et al. 2020). Antibodies are immunoglobulins that our immune system produces to neutralize the pathogens. Convalescent plasma therapy (CPT), typical adaptive immunotherapy, has been exercised in the prevention and treatment of ancient pandemics such as SARS, MERS, 2009 H1N1. In 2014, WHO recommended the CPT for Ebola virus disease treatment (Van Bavel et al. 2020; Bansal et al. 2020). The concept of CPT is to utilize plasma, the opaque liquid part of the blood from a recovered patient who has developed humoral immunity that able to remove or neutralize the virus. It is used to treat during the occurrence of severe adverse conditions, but the clinical benefits and peril of this therapy for COVID-19 still uncertain (Bansal et al. 2020). Therefore, it will be worthwhile to examine its efficacy and safety measures.

To bring this pandemic to an end, many research teams across the world developed vaccines that protect from SAR-CoV-2, the virus that causes COVID-19. As of now several vaccines are available, among which national regulatory authority have granted emergency use authorization for sixteen vaccines, and currently vaccine has been administered worldwide. Some of the recommended vaccines are CoronaVac, Covaxin, Sputnik V, Oxford-AstraZeneca, Convidecia, PfizerBioNTech, Moderna, etc. However, some drug molecules believed to be effective, have reviewed in Table 1 . Antiretroviral treatments like Lopinavir and Ritonavir are also under clinical trials. The overactive and maladjustive inflammatory response is thought to targeted with anti-inflammatory drug molecules such as AMY101, Ravulizumab and Ifenprodil which are registered under investigation (Zhai et al. 2020; Lythgoe and Middleton 2020). All current authorized and recommended vaccines are categorized under four major types, mRNA vaccines, inactivated virus vaccines, adenovirus vector vaccines and protein subunit vaccines. mRNA vaccines are those in which a copy of natural mRNA used that can gear up strong immune response. Inactivated virus vaccines consisting of destroyed disease producing viral 
Table 1 Illustrate a few potential treatments for COVID-19 approved for human clinical trials

\begin{tabular}{|c|c|c|}
\hline Vaccine/drug molecule & Clinical trials & Description \\
\hline ADZ1222 (ChAdO $\times 1$ nCoV-19) & NCT0432606 & $\begin{array}{l}\text { Attenuated Adenovirus exhibit SARS-CoV-2 spike protein in its surface } \\
\text { (Zhang et al. 2020b; Cai et al. 2020) }\end{array}$ \\
\hline Ad5-nCoV & NCT04313127, NCT04341389, NCT04398147 & $\begin{array}{l}\text { Replication-impaired Adenovirus integrated with a full length nCoV-19 } \\
\text { spike protein (Shi et al. 2020; Lythgoe and Middleton 2020) }\end{array}$ \\
\hline INO-4800 & NCT04336410 & $\begin{array}{l}\text { Based on plasmid DNA encoded with antigens found in nCoV-19 (Le } \\
\text { et al. 2020) }\end{array}$ \\
\hline AMY-101 & NCT04395456 & $\begin{array}{l}\text { Pro-inflammatory complement system C3 blockade agent and hope } \\
\text { with C5a inactivation (Zhou et al. 2019; Mastaglio et al. 2020) }\end{array}$ \\
\hline Ravulizumab & NCT04369469, NCT04390464 & $\begin{array}{l}\text { Monoclonal antibody-based treatment that halts the activation of } \\
\text { inflammatory component system C5 (Zhou et al. 2019; Lee et al. 2019; } \\
\text { Kulasekararaj et al. 2019) }\end{array}$ \\
\hline Baricitinib & NCT04321993, NCT04345289, NCT04393051 & $\begin{array}{l}\text { It is aimed to inhibit JAK/STAT signaling pathway to reduce cytokine } \\
\text { production (Richardson et al. 2020) }\end{array}$ \\
\hline Ifenprodil & NCT04382924 & $\begin{array}{l}\text { It is an N-methyl-D-Aspartate inhibitor targeted to alleviate T-cell } \\
\text { cytokine production (Allen et al. 2020) }\end{array}$ \\
\hline Interferon-a & NCT04320238 & $\begin{array}{l}\text { It is a cytokine mainly produced by the immune system to fight against } \\
\text { the army of a virus (Cao et al. 2020) }\end{array}$ \\
\hline Convalescent plasma & NCT04321421, NCT04338360, NCT04397757 & $\begin{array}{l}\text { Plasma-based immunotherapy, obtained from COVID-19 recovered } \\
\text { patient, which contain specific antibiotics, enzymes and essential pro- } \\
\text { teins that may be protective against nCoV-19 (Liu et al. 2020a; Chen } \\
\text { et al. 2020; Shen et al. 2020; Duan et al. 2020; Bloch et al. 2020) }\end{array}$ \\
\hline Ribavirin & NCT04356677, NCT04276688 & $\begin{array}{l}\text { It is a nucleoside analog antiviral molecule induce mutation in the viral } \\
\text { genome that can be lethal (Li et al. 2020b; Guo et al. 2020; Dong et al. } \\
\text { 2020; Khalili et al. 2020; Hung et al. 2020) }\end{array}$ \\
\hline Remdesivir & NCT04292730, NCT04280705, NCT04373044 & $\begin{array}{l}\text { A nucleoside analog antiviral drug that interferes with SARS-CoV-2 } \\
\text { replication (Devaux et al. 2020; Wu et al. 2020a; Wang et al. 2020; Grein } \\
\text { et al. 2020) }\end{array}$ \\
\hline Ritonavir & NCT04321993, NCT04350684, NCT04366245 & $\begin{array}{l}\text { It is a protease inhibitor that can be very effective by inhibiting viral pro- } \\
\text { teases and host proteases that degrade antivirals (Huang et al. 2020; } \\
\text { Dariya and Nagaraju 2020; Lim et al. 2020; Cao et al. 2020) }\end{array}$ \\
\hline Lopinavir & NCT04303299, NCT04255017, NCT04376814 & $\begin{array}{l}\text { It is an anti-retroviral drug that works by binding with viral proteases } \\
\text { (Shetty et al. 2020; Chandel et al. 2020; Cao et al. 2020) }\end{array}$ \\
\hline Artemisinin & NCT04387240, NCT043872040 & $\begin{array}{l}\text { It is also used to treat malaria but believed to have antiviral properties } \\
\text { (SEHAILIA 2020; Smit et al. 2020) }\end{array}$ \\
\hline
\end{tabular}

particle, whereas adenovirus vector vaccines are the vaccines that use pathogen genes in order to stimulate good immune response, genes used are generally antigens coding surface protein of the coronavirus. The protein subunit vaccines contain one or more antigens (fragments of pathogens). The humanity has often relied on vaccination technology in the past in order to bring down the infection and deaths causing by infection. The vaccines basically stimulate immune system and build T-lymphocytes and B-lymphocytes which will recognize the virus and remember how to protect and fight with virus causing COIVD-19 in future infection.

\section{Conclusions}

The world has experienced coronavirus epidemic first in 2002 of SARS-CoV, then 2012 of MERS-CoV and currently experiencing SARS-CoV-2. No doubt, this outbreak is highly warning by inducing serious illness, human-to-human transmission and rapid rate of spreading infection that declared as a pandemic. SARSCoV-2 enters into the lung cells by binding with ACE2, along with cells of other organs such as liver, gastrointestinal organ and kidney are also vulnerable due to expression of ACE2 receptors. Coronavirus disease 2019 causes severe sickness, whereas our immune system is fueling new tension on the response that may lead to ARDS and even multi-organ failure. Controlling the complement system, which is responsible for the maladaptive inflammatory response, can be an essential factor in developing potential therapeutic drug candidates. The present scenario of pandemic 2019 is acutely worsening and needs immediate action which can limp back to normalcy. Therefore, the purpose of developing COVID-19 treatments should focus on controlling the maladjustive immune system along with virus clearance. There are many pharmaceutical industries in the race to scale up new therapeutics that can interfere at any stage of the coronavirus infection cycle. 
Vaccines being developed and its inoculation has begun, but deep research is needed to upgrade a better understanding of coronavirus and their interaction with the host cell. Openness and sharing of scrutinized data are paramount. Increasing our understanding of coronavirus can expand opportunities not only in rational design and development of therapeutics but also to target new coronavirus in future emergence.

\begin{abstract}
Abbreviations
ACE2: Angiotensin-converting enzyme 2; ALI: Acute lung injury; ARDS: Acute respiratory distress syndrome; BALF: Bronchoalveolar lavage fluid; CDC: Centre of disease control; COVID-19: Coronavirus disease 2019; CPT: Covalescent plasma therapy; DAMPs: Damage-associated molecular patterns; ERGIC: Endoplasmic reticulum to Golgi intermediate complex; FDA: Food and drug administration; HAT: Human airway trypsin-like protease; ICTV: International committee on taxonomy of virus; IFN: Interferons; ISGs: Interferon stimulating genes; MERS: Middle East respiratory syndrome; MIP: Macrophages inflammatory proteins; $\mathrm{nCoV}$ : Novel corona virus; NK: Natural killer cells; NLR: Nod-like receptor; NSPs: Nonstructural proteins; ORF: Open reading frame; PAMPs: Pathogen-associated molecular patterns; PRR: Pathogen recognition receptor; ROS: Reactive oxygen species; RTC: Replication-transcription complex; SARS: Severe acute respiratory syndrome; TLR: Toll-like receptor; TNF:Tumor necrosis factor; WHO: World Health Organization.
\end{abstract}

\section{Acknowledgements}

The author gratefully acknowledge the P.G Department of Botany, Berhampur University, for providing excellent facilities during the study.

\section{Authors' contributions}

$\mathrm{PH}$ conceptualized and write the manuscript, did proof reading, editing and correspondence. Author have read and approved the manuscript.

\section{Funding}

Not applicable.

\section{Availability of data and materials}

Not applicable.

\section{Declarations}

Ethics approval and consent to participate

Not applicable.

\section{Consent for publication}

Not applicable.

\section{Competing interests}

The author declare no competing interest.

Received: 16 April 2021 Accepted: 1 July 2021

Published online: 09 July 2021

\section{References}

Acter T, Uddin N, Das J, Akhter A, Choudhury TR, Kim S (2020) Evolution of severe acute respiratory syndrome coronavirus 2 (SARS-CoV-2) as coronavirus disease 2019 (COVID-19) pandemic: A global health emergency. Sci Total Environ 730:138996

Allen C, Arjona S, Santerre M (2020) Potential use of RNA-dependent RNA polymerase (RdRp) inhibitor against COVID-19 infection. All Life 13:608-614

Ashour HM, Elkhatib WF, Rahman M, Elshabrawy HA (2020) Insights into the recent 2019 novel coronavirus (SARS-CoV-2) in light of past human coronavirus outbreaks. Pathogens 9(3):186
Bansal P, Bingemann TA, Greenhawt M, Mosnaim G, Nanda A, Oppenheimer J, Sharma H, Stukus D, Shaker M (2020) Clinician wellness during the COVID-19 pandemic: extraordinary times and unusual challenges for the allergist/immunologist. J Allergy Clin Immunol Pract 8:1781-1790

Bloch EM, Shoham S, Casadevall A, Sachais BS, Shaz B, Winters JL, van Buskirk C, Grossman BJ, Joyner M, Henderson JP (2020) Deployment of convalescent plasma for the prevention and treatment of COVID-19. J Clin Investig 130:2757-2765

Brown K, Wang RC (2020) Politics and science: the case of china and the coronavirus. Asian Affairs 51:1-18

Cai Y, Yin D, Ling S, Tian X, Li Y, Xu Z, Jiang H, Zhang X, Wang X, Shi Y (2020) A single dose SARS-CoV-2 simulating particle vaccine induces potent neutralizing activities. bioRxiv

Cao B, Wang Y, Wen D, Liu W, Wang J, Fan G, Ruan L, Song B, Cai Y, Wei M (2020) A trial of lopinavir-ritonavir in adults hospitalized with severe Covid-19. N Engl I Med

Cascella M, Rajnik M, Cuomo A, Dulebohn SC, Di Napoli R (2020) Features, evaluation and treatment coronavirus (COVID-19). In: Statpearls [internet]. StatPearls Publishing

Chandel V, Raj S, Rathi B, Kumar D (2020) In silico identification of potent COVID-19 main protease inhibitors from FDA approved antiviral compounds and active phytochemicals through molecular docking: a drug repurposing approach

Channappanavar R, Perlman S (2017) Pathogenic human coronavirus infections: causes and consequences of cytokine storm and immunopathology. In: Seminars in immunopathology, vol 5. Springer, pp 529-539

Chaudhary NK, Chaudhary N, Dahal M, Guragain B, Rai S, Chaudhary R, Sachin K, Lamichhane-Khadka R, Bhattarai A (2020) Fighting the SARS CoV-2 (COVID-19) pandemic with soap

Chen L, Xiong J, Bao L, Shi Y (2020) Convalescent plasma as a potential therapy for COVID-19. Lancet Infect Dis 20(4):398-400

Connors JM, Levy JH (2020) COVID-19 and its implications for thrombosis and anticoagulation. Blood 135:2033-2040

Coperchini F, Chiovato L, Croce L, Magri F, Rotondi M (2020) The Cytokine storm in COVID-19: an overview of the involvement of the chemokine/ chemokine-receptor system. Cytokine Growth Factor Rev 53:25-32

Dariya B, Nagaraju GP (2020) Understanding novel COVID-19: its impact on organ failure and risk assessment for diabetic and cancer patients. Cytokine Growth Factor Rev 53:43-52

Daughton CG (2020) Natural experiment concept to accelerate the re-purposing of existing therapeutics for Covid-19. Glob Epidemiol 2:100026

Devaux CA, Rolain J-M, Colson P, Raoult D (2020) New insights on the antiviral effects of chloroquine against coronavirus: what to expect for COVID19? Int J Antimicrob Agents 55:105938

Dong L, Hu S, Gao J (2020) Discovering drugs to treat coronavirus disease 2019 (COVID-19). Drug Discov Therap 14(1):58-60

Driggin E, Madhavan MV, Bikdeli B, Chuich T, Laracy J, Biondi-Zoccai G, Brown TS, Der Nigoghossian C, Zidar DA, Haythe J (2020) Cardiovascular considerations for patients, health care workers, and health systems during the COVID-19 pandemic. J Am Coll Cardiol 75(18):2352-2371

Duan K, Liu B, Li C, Zhang H, Yu T, Qu J, Zhou M, Chen L, Meng S, Hu Y (2020) Effectiveness of convalescent plasma therapy in severe COVID-19 patients. Proc Natl Acad Sci 117(17):9490-9496

Felsenstein S, Herbert JA, McNamara PS, Hedrich CM (2020) COVID-19: immunology and treatment options. Clin Immunol 215:108448

Geng Y-J, Wei Z-Y, Qian H-Y, Huang J, Lodato R, Castriotta RJ (2020) Pathophysiological characteristics and therapeutic approaches for pulmonary injury and cardiovascular complications of coronavirus disease 2019. Cardiovasc Pathol 47:107228

Ghias MH, Hyde MJ, Tomalin LE, Morgan BP, Alavi A, Lowes MA, Piguet V (2020) Role of the complement pathway in inflammatory skin diseases: a focus on hidradenitis suppurativa. J Investig Dermatol 140(3):531-536

Gou W, Fu Y, Yue L, Chen G-d, Cai X, Shuai M, Xu F, Yi X, Chen H, Zhu YJ (2020) Gut microbiota may underlie the predisposition of healthy individuals to COVID-19. medRxiv

Grein J, Ohmagari N, Shin D, Diaz G, Asperges E, Castagna A, Feldt T, Green G, Green ML, Lescure F-X (2020) Compassionate use of remdesivir for patients with severe Covid-19. N Engl J Med 382:2327-2336

Guo Y-R, Cao Q-D, Hong Z-S, Tan Y-Y, Chen S-D, Jin H-J, Tan K-S, Wang D-Y, Yan $Y$ (2020) The origin, transmission and clinical therapies on coronavirus 
disease 2019 (COVID-19) outbreak—an update on the status. Mil Med Res 7(1):1-10

Hashimoto N, Kawabe T, Imaizumi K, Hara T, Okamoto M, Kojima K, Shimokata K, Hasegawa Y (2004) CD40 plays a crucial role in lipopolysaccharideinduced acute lung injury. Am J Respir Cell Mol Biol 30(6):808-815

Hoffmann M, Kleine-Weber H, Schroeder S, Krüger N, Herrler T, Erichsen S, Schiergens TS, Herrler G, Wu N-H, Nitsche A (2020) SARS-CoV-2 cell entry depends on ACE2 and TMPRSS2 and is blocked by a clinically proven protease inhibitor. Cell 181:271-280

Hu J, Mo Y, Gao Z, Wang X, Gu M, Liang Y, Cheng X, Hu S, Liu W, Liu H (2016) PA$X$-associated early alleviation of the acute lung injury contributes to the attenuation of a highly pathogenic $\mathrm{H} 5 \mathrm{~N} 1$ avian influenza virus in mice. Med Microbiol Immunol 205(4):381-395

Huang J, Song W, Huang H, Sun Q (2020) Pharmacological therapeutics targeting rna-dependent rna polymerase, proteinase and spike protein: from mechanistic studies to clinical trials for COVID-19. J Clin Med 9(4):1131

Hung IF-N, Lung K-C, Tso EY-K, Liu R, Chung TW-H, Chu M-Y, Ng Y-Y, Lo J, Chan $J$, Tam AR (2020) Triple combination of interferon beta-1 b, lopinavirritonavir, and ribavirin in the treatment of patients admitted to hospital with COVID-19: an open-label, randomised, phase 2 trial. The Lancet 395:1695-1704

Jalava K (2020) First respiratory transmitted food borne outbreak? Int J Hyg Environ Health 226:113490

Jiang Y, Zhao G, Song N, Li P, Chen Y, Guo Y, Li J, Du L, Jiang S, Guo R (2018) Blockade of the $\mathrm{C} 5 \mathrm{a}-\mathrm{C} 5 \mathrm{aR}$ axis alleviates lung damage in hDPP4-transgenic mice infected with MERS-CoV. Emerg Microbes Infect 7(1):1-12

Jin Y-H, Cai L, Cheng Z-S, Cheng H, Deng T, Fan Y-P, Fang C, Huang D, Huang $\mathrm{L}-\mathrm{Q}$, Huang Q (2020a) A rapid advice guideline for the diagnosis and treatment of 2019 novel coronavirus (2019-nCoV) infected pneumonia (standard version). Mil Med Res 7(1):4

Jin Y, Yang H, Ji W, Wu W, Chen S, Zhang W, Duan G (2020b) Virology, epidemiology, pathogenesis, and control of COVID-19. Viruses 12(4):372

Khalili JS, Zhu H, Mak NSA, Yan Y, Zhu Y (2020) Novel coronavirus treatment with ribavirin: Groundwork for an evaluation concerning COVID-19. J Med Virol 92:740-746

Khan S, Siddique R, Shereen MA, Ali A, Liu J, Bai Q, Bashir N, Xue M (2020) Emergence of a novel coronavirus, severe acute respiratory syndrome coronavirus 2: biology and therapeutic options. J Clin Microbiol 58(5):e00187-20

Kim J-M, Chung Y-S, Jo HJ, Lee N-J, Kim MS, Woo SH, Park S, Kim JW, Kim HM, Han M-G (2020) Identification of coronavirus isolated from a patient in Korea with COVID-19. Osong Public Health Res Perspect 11(1):3

Kulasekararaj AG, Hill A, Rottinghaus ST, Langemeijer S, Wells R, Gonzalez-Fernandez FA, Gaya A, Lee JW, Gutierrez EO, Piatek CI (2019) Ravulizumab (ALXN1210) vs eculizumab in C5-inhibitor-experienced adult patients with PNH: the 302 study. Blood 133(6):540-549

Kumar M, Taki K, Gahlot R, Sharma A, Dhangar K (2020) A chronicle of SARSCoV-2: part---epidemiology, diagnosis, prognosis, transmission and treatment. Sci Total Environ 734:139278

Lai C-C, Shih T-P, Ko W-C, Tang H-J, Hsueh P-R (2020) Severe acute respiratory syndrome coronavirus 2 (SARS-CoV-2) and corona virus disease-2019 (COVID-19): the epidemic and the challenges. Int J Antimicrob Agents 55:105924

Le TT, Andreadakis Z, Kumar A, Roman RG, Tollefsen S, Saville M, Mayhew S (2020) The COVID-19 vaccine development landscape. Nat Rev Drug Discov 19:305-306

Lee JW, Sicre de Fontbrune F, Wong Lee Lee L, Pessoa V, Gualandro S, Füreder W, Ptushkin V, Rottinghaus ST, Volles L, Shafner L (2019) Ravulizumab (ALXN1210) vs eculizumab in adult patients with PNH naive to complement inhibitors: the 301 study. Blood 133(6):530-539

Lega S, Naviglio S, Volpi S, Tommasini A (2020) Recent Insight into SARS-CoV2 immunopathology and rationale for potential treatment and preventive strategies in COVID-19. Vaccines 8(2):224

Li J, Ma Q, Liu H, Song X, Pang Y, Su P, Sun F, Gou M, Lu J, Shan Y (2020a) Complement component C1q plays a critical role in VLRANVLRC-mediated immune response. Dev Comp Immunol 111:103750

Li X, Geng M, Peng Y, Meng L, Lu S (2020b) Molecular immune pathogenesis and diagnosis of COVID-19. J Pharmaceut Anal 10:102-108

Lim J, Jeon S, Shin H-Y, Kim MJ, Seong YM, Lee WJ, Choe K-W, Kang YM, Lee B, Park S-J (2020) Case of the index patient who caused tertiary transmission of COVID-19 infection in Korea: the application of lopinavir/ ritonavir for the treatment of COVID-19 infected pneumonia monitored by quantitative RT-PCR. J Korean Med Sci 35(6):e79-e79

Liu C, Zhou Q, Li Y, Garner LV, Watkins SP, Carter LJ, Smoot J, Gregg AC, Daniels AD, Jervey S (2020a) Research and development on therapeutic agents and vaccines for COVID-19 and related human coronavirus diseases. ACS Publications

Liu K, Fang Y-Y, Deng Y, Liu W, Wang M-F, Ma J-P, Xiao W, Wang Y-N, Zhong M-H, Li C-H (2020b) Clinical characteristics of novel coronavirus cases in tertiary hospitals in Hubei Province. Chin Med J 133:1025

Ludwig C, Wagner R (2007) Virus-like particles-universal molecular toolboxes. Curr Opin Biotechnol 18(6):537-545

Lythgoe MP, Middleton P (2020) Ongoing clinical trials for the management of the COVID-19 pandemic. Trends Pharmacol Sci 41:363-382

Magro C, Mulvey JJ, Berlin D, Nuovo G, Salvatore S, Harp J, Baxter-Stoltzfus A, Laurence J (2020) Complement associated microvascular injury and thrombosis in the pathogenesis of severe COVID-19 infection: a report of five cases. Transl Res 220:1-13

Malik YS, Kumar N, Sircar S, Kaushik R, Bhatt S, Dhama K, Gupta P, Goyal K, Singh MP, Ghoshal U (2020) Pandemic coronavirus disease (COVID-19): challenges and a global perspective

Mastaglio S, Ruggeri A, Risitano AM, Angelillo P, Yancopoulou D, Mastellos DC, Huber-Lang M, Piemontese S, Assanelli A, Garlanda C (2020) The first case of COVID-19 treated with the complement C3 inhibitor AMY-101. Clin Immunol 215:108450

Misra DP, Agarwal V, Gasparyan AY, Zimba O (2020) Rheumatologists' perspective on coronavirus disease 19 (COVID-19) and potential therapeutic targets. Clin Heumatol 39:1-8

Moccia F, Gerbino A, Lionetti V, Miragoli M, Munaron L, Pagliaro P, Pasqua T, Penna C, Rocca C, Samaja M (2020) COVID-19-associated cardiovascular morbidity in older adults: a position paper from the Italian Society of Cardiovascular Researches. GeroScience 42:1-29

Nandy A (2019) COVID-19: an enigma which has engulfed the world

Neurath MF (2020) Covid-19 and immunomodulation in IBD. Gut 69:1335-1342

Noris M, Benigni A, Remuzzi G (2020) The case of Complement activation in COVID-19 multiorgan impact. Kidney Int 98:314-322

Pal M, Berhanu G, Desalegn C, Kandi V (2020) Severe acute respiratory syndrome coronavirus-2 (SARS-CoV-2): an update. Cureus 12(3)

Paudel S, Dangal G, Chalise A, Bhandari TR, Dangal O (2020) The coronavirus pandemic: what does the evidence show? J Nepal Health Res Counc 18(2):1-9

Peeri NC, Shrestha N, Rahman MS, Zaki R, Tan Z, Bibi S, Baghbanzadeh M, Aghamohammadi N, Zhang W, Haque U (2020) The SARS, MERS and novel coronavirus (COVID-19) epidemics, the newest and biggest global health threats: what lessons have we learned? Int J Epidemiol 49:717-726

Pillaiyar T, Meenakshisundaram S, Manickam M (2020) Recent discovery and development of inhibitors targeting coronaviruses. Drug Discov Today 25:668-688

Porcheddu R, Serra C, Kelvin D, Kelvin N, Rubino S (2020) Similarity in case fatality rates (CFR) of COVID-19/SARS-COV-2 in Italy and China. J Infect Dev Countries 14(02):125-128

Prompetchara E, Ketloy C, Palaga T (2020) Immune responses in COVID-19 and potential vaccines: lessons learned from SARS and MERS epidemic. Asian Pac J Allergy Immunol 38(1):1-9

Puneet P, Moochhala S, Bhatia M (2005) Chemokines in acute respiratory distress syndrome. Am J Physiol Lung Cell Mol Physiol 288(1):L3-L15

Rajaei S, Dabbagh A (2020) The immunologic basis of COVID-19: a clinical approach. J Cell Mol Anesth 5(1):37-42

Repici A, Maselli R, Colombo M, Gabbiadini R, Spadaccini M, Anderloni A, Carrara S, Fugazza A, Di Leo M, Galtieri PA (2020) Coronavirus (COVID-19) outbreak: what the department of endoscopy should know. Gastrointest Endosc 92:192-197

Richardson P, Griffin I, Tucker C, Smith D, Oechsle O, Phelan A, Stebbing J (2020) Baricitinib as potential treatment for 2019-nCoV acute respiratory disease. Lancet (London, England) 395(10223):e30

Rogosnitzky M, Okediji P, Koman I (2020) Cepharanthine: a review of the antiviral potential of a Japanese-approved alopecia drug in COVID-19

Russell B, Moss C, George G, Santaolalla A, Cope A, Papa S, Van Hemelrijck M (2020) Associations between immune-suppressive and stimulating 
drugs and novel COVID-19-a systematic review of current evidence. ecancermedicalscience 14

Safdar M, Yasmin M (2020) COVID-19: a threat to educated Muslim women's negotiated identity in Pakistan. Gender, Work \& Organization

Sehailia M (2020) In-silico studies of antimalarial-agent artemisinin and derivatives portray more potent binding to Lys 353 and Lys31-binding hotspots of SARS-CoV-2 spike protein than hydroxychloroquine: potential repurposing of artenimol for COVID-19

Sen S, Antara N, Sen S, Chowdhury S (2020) The Unprecedented pandemic 'COVID-19' effect on the Bangladesh apparel workers by shivering the apparel supply chain. Available at SSRN 3598542

Shafiq M, Qurashi F, Mushtaq S, Hussain M, Hameed A, Haider MS (2020) DNA plant viruses: biochemistry, replication, and molecular genetics. In: Applied plant virology. Elsevier, pp 169-182

Shen C, Wang Z, Zhao F, Yang Y, Li J, Yuan J, Wang F, Li D, Yang M, Xing L (2020) Treatment of 5 critically ill patients with COVID-19 with convalescent plasma. JAMA 323(16):1582-1589

Shereen MA, Khan S, Kazmi A, Bashir N, Siddique R (2020) COVID-19 infection: origin, transmission, and characteristics of human coronaviruses. J Adv Res 24:91-98

Shetty R, Ghosh A, Honavar SG, Khamar P, Sethu S (2020) Therapeutic opportunities to manage COVID-19/SARS-CoV-2 infection: present and future. Indian J Ophthalmol 68(5):693

Shi Y, Wang N, Zou Q (2020) Progress and challenge of vaccine development against 2019 novel coronavirus (2019-nCoV). Zhonghua Yu Fang Yi Xue Za Zhi [chin J Prevent Med] 54:E029-E029

Singhal T (2020) A review of coronavirus disease-2019 (COVID-19). Indian 」 Pediatr 87:1-6

Smit C, Peeters MY, van den Anker JN, Knibbe CA (2020) Chloroquine for SARS-CoV-2: implications of its unique pharmacokinetic and safety properties. Clin Pharmacokinet 59:1

Smole U, Kratzer B, PickI WF (2020) Soluble pattern recognition molecules: guardians and regulators of homeostasis at airway mucosal surfaces. Eur J Immunol 50(5):624-642

Song Z, Xu Y, Bao L, Zhang L, Yu P, Qu Y, Zhu H, Zhao W, Han Y, Qin C (2019) From SARS to MERS, thrusting coronaviruses into the spotlight. Viruses 11(1):59

South AM, Diz DI, Chappell MC (2020) COVID-19, ACE2, and the cardiovascular consequences. Am J Physiol Heart Circul Physiol 318(5):H1084-H1090

Tay MZ, Poh CM, Rénia L, MacAry PA, Ng LF (2020) The trinity of COVID-19: immunity, inflammation and intervention. Nat Rev Immunol 20:1-12

To KK-W, Tsang OT-Y, Leung W-S, Tam AR, Wu T-C, Lung DC, Yip CC-Y, Cai J-P, Chan JM-C, Chik TS-H (2020) Temporal profiles of viral load in posterio oropharyngeal saliva samples and serum antibody responses during infection by SARS-CoV-2: an observational cohort study. Lancet Infect Dis 20:565-574

Van Bavel JJ, Baicker K, Boggio PS, Capraro V, Cichocka A, Cikara M, Crockett MJ, Crum AJ, Douglas KM, Druckman JN (2020) Using social and behavioural science to support COVID-19 pandemic response. Nat Hum Behav 4:1-12

Vennema H, Godeke G-J, Rossen J, Voorhout W, Horzinek M, Opstelten D, Rottier P (1996) Nucleocapsid-independent assembly of coronavirus-like particles by co-expression of viral envelope protein genes. EMBO J 15(8):2020-2028

Wan Y, Shang J, Graham R, Baric RS, Li F (2020) Receptor recognition by the novel coronavirus from Wuhan: an analysis based on decade-long structural studies of SARS coronavirus. J Virol 94(7):e00127-20

Wang Y, Zhang D, Du G, Du R, Zhao J, Jin Y, Fu S, Gao L, Cheng Z, Lu Q (2020) Remdesivir in adults with severe COVID-19: a randomised, doubleblind, placebo-controlled, multicentre trial. The Lancet 395:1569-1578

Wilder-Smith A, Chiew CJ, Lee VJ (2020) Can we contain the COVID-19 outbreak with the same measures as for SARS? Lancet Infect Dis 20:e102-e107

Wu C, Liu Y, Yang Y, Zhang P, Zhong W, Wang Y, Wang Q, Xu Y, Li M, Li X (2020a) Analysis of therapeutic targets for SARS-CoV-2 and discovery of potential drugs by computational methods. Acta Pharm Sin B 10:766-788

Wu P, Hao X, Lau EH, Wong JY, Leung KS, Wu JT, Cowling BJ, Leung GM (2020b) Real-time tentative assessment of the epidemiological characteristics of novel coronavirus infections in Wuhan, China, as at 22 January 2020. Eurosurveillance 25(3):2000044

Wu Y, Xu X, Chen Z, Duan J, Hashimoto K, Yang L, Liu C, Yang C (2020c) Nervous system involvement after infection with COVID-19 and other coronaviruses. Brain Behav Immun 87:18-22

Xiang M, Fan J (2010) Pattern recognition receptor-dependent mechanisms of acute lung injury. Mol Med 16(1-2):69-82

Yang Y, Peng F, Wang R, Guan K, Jiang T, Xu G, Sun J, Chang C (2020) The deadly coronaviruses: The 2003 SARS pandemic and the 2020 novel coronavirus epidemic in China. J Autoimmun 109:102434

Yi Y, Lagniton PN, Ye S, Li E, Xu R-H (2020) COVID-19: what has been learned and to be learned about the novel coronavirus disease. Int J Biol Sci 16(10):1753

Zhai P, Ding Y, Wu X, Long J, Zhong Y, Li Y (2020) The epidemiology, diagnosis and treatment of COVID-19. Int J Antimicrob Agents 55:105955

Zhang H, Penninger JM, Li Y, Zhong N, Slutsky AS (2020a) Angiotensin-converting enzyme 2 (ACE2) as a SARS-CoV-2 receptor: molecular mechanisms and potential therapeutic target. Intensive Care Med 46:1-5

Zhang J, Zeng H, Gu J, Li H, Zheng L, Zou Q (2020b) Progress and prospects on vaccine development against SARS-CoV-2. Vaccines 8(2):153

Zhang L, Liu Y (2020) Potential interventions for novel coronavirus in China: a systematic review. J Med Virol 92(5):479-490

Zhang R, Wang X, Ni L, Di X, Ma B, Niu S, Liu C, Reiter RJ (2020c) COVID-19: melatonin as a potential adjuvant treatment. Life Sci 250:117583

Zhou H, Hara H, Cooper DK (2019) The complex functioning of the complement system in xenotransplantation. Xenotransplantation 26(4):e12517

Zhu N, Zhang D, Wang W, Li X, Yang B, Song J, Zhao X, Huang B, Shi W, Lu R (2020) A novel coronavirus from patients with pneumonia in China, 2019. N Engl J Med 382:727-733

\section{Publisher's Note}

Springer Nature remains neutral with regard to jurisdictional claims in published maps and institutional affiliations.

\section{Submit your manuscript to a SpringerOpen ${ }^{\circ}$ journal and benefit from:}

- Convenient online submission

- Rigorous peer review

- Open access: articles freely available online

- High visibility within the field

Retaining the copyright to your article

Submit your next manuscript at $\boldsymbol{\nabla}$ springeropen.com 